University of Nebraska - Lincoln

DigitalCommons@University of Nebraska - Lincoln

\title{
8-2013
}

\section{Inconsistent Outcomes of Heterogeneity-Based Management Underscore Importance of Matching Evaluation to Conservation Objectives}

\author{
Devan Allen McGranahan \\ lowa State University, mcgranah@alumni.grinnell.edu \\ David M. Engle \\ Oklahoma State University, david.engle@okstate.edu \\ Samuel D. Fuhlendorf \\ Oklahoma State University, sam.fuhlendorf@okstate.edu \\ Stephen L. Winter \\ Oklahoma State University, wintersl8944@gmail.com \\ James R. Miller \\ University of Illinois, Urbana, jrmillr@illinois.edu
}

See next page for additional authors

Follow this and additional works at: https://digitalcommons.unl.edu/natrespapers

Part of the Natural Resources and Conservation Commons, Natural Resources Management and

Policy Commons, and the Terrestrial and Aquatic Ecology Commons

McGranahan, Devan Allen; Engle, David M.; Fuhlendorf, Samuel D.; Winter, Stephen L.; Miller, James R.; and Debinski, Diane M., "Inconsistent Outcomes of Heterogeneity-Based Management Underscore Importance of Matching Evaluation to Conservation Objectives" (2013). Papers in Natural Resources. 401.

https://digitalcommons.unl.edu/natrespapers/401

This Article is brought to you for free and open access by the Natural Resources, School of at DigitalCommons@University of Nebraska - Lincoln. It has been accepted for inclusion in Papers in Natural Resources by an authorized administrator of DigitalCommons@University of Nebraska - Lincoln. 


\section{Authors}

Devan Allen McGranahan, David M. Engle, Samuel D. Fuhlendorf, Stephen L. Winter, James R. Miller, and Diane M. Debinski 


\title{
Inconsistent outcomes of heterogeneity-based management underscore importance of matching evaluation to conservation objectives
}

\author{
Devan Allen McGranahan, ${ }^{1}$ David M. Engle,${ }^{2}$ Samuel D. Fuhlendorf, ${ }^{2}$ \\ Stephen L. Winter, ${ }^{2}$ James R. Miller, ${ }^{3}$ and Diane M. Debinski ${ }^{4}$
}

1. Rangeland Ecology Lab, Department of Natural Resource Ecology and Management, Iowa State University, Ames, IA, USA

2. Department of Natural Resource Ecology and Management, Oklahoma State University, Stillwater, OK, USA

3. Department of Natural Resources and Environmental Sciences, University of Illinois, Urbana, IL, USA

4. Department of Ecology Evolution and Organismal Biology, Iowa State University, Ames, IA, USA

Corresponding author - D. A. McGranahan, Department of Environmental Studies, 735 University Avenue, The University of the South, Sewanee, TN 37375, USA; tel 515 708-5148, fax 931 598-1145, email mcgranah@alumni.grinnell.edu

\begin{abstract}
Conservation policy often incentivizes managers of human-impacted areas to create landscape heterogeneity to maximize biodiversity. In rangeland, patchy disturbance regimes create landscape heterogeneity (patch contrast), but outcomes of heterogeneity-based management are rarely tested for a universal response. We analyzed four habitat variables - vegetation structure, plant functional group composition, litter cover, and bare ground-from five experimental rangelands in Oklahoma and Iowa, USA. We tested for response consistency to heterogeneity-based management across and within locations. We calculated effect sizes for each variable to compare patch contrast on pastures managed for heterogeneity (patch burn-grazing) and pastures managed for homogeneity (grazing with homogeneous fire regimes). Effects varied considerably across and within locations. Effects of heterogeneity-based management were positive for all variables at only three of five experimental rangeland locations. No location showed a consistent pattern of positive effect across all four variables, although one location showed no effect for any variable. At another location, we found a positive effect of heterogeneity-based management on litter cover and bare ground, but no effect on vegetation structure and plant functional group composition. We discuss effect variability and how the fire-grazing interaction applies to rangeland management and conservation. Although it is accepted practice to use heterogeneity-based management to increase rangeland habitat diversity, managers should also confirm that evaluation metrics match desired conservation outcomes.
\end{abstract}

Keywords: fire-grazing interaction, habitat management, meta-analysis, patch burn-grazing, pyric-herbivory, rangeland biodiversity 


\section{Introduction}

Heterogeneity and patchiness are central themes in environmental management (Ostfeld, 1997, Wiens, 1997) and have been suggested as specific goals of conservation policy (Benton et al., 2003, Fischer et al., 2008, 2006). Policy emphasis stems from growing evidence that heterogeneity enhances biodiversity, especially in human-impacted landscapes (Franklin and Lindenmayer, 2009, Ricketts et al., 2001, Tews et al., 2004). At the same time, it is important that heterogeneity-based conservation programs are cost-effective and ecologically sound (Drechsler et al., 2007, Ohl et al., 2008, Toombs and Roberts, 2009).

Essential to the assessment of conservation programs are appropriate monitoring and understanding of the ecological drivers of landscape heterogeneity (Eyre et al., 2011, Wallington et al., 2005). Heterogeneity results from variation in the extent, frequency, and intensity of abiotic and biotic processes, including disturbance (Fraterrigo and Rusak, 2008, Pickett and White, 1985). Throughout the evolutionary history of many rangeland ecosystems, fire and grazing have been influential disturbances affecting heterogeneity (Allred et al., 2011). In managed rangeland, prescribed fire is applied in discrete patches to replicate the spatially- and temporally-shifting mosaic of pre-European landscapes (Fuhlendorf and Engle, 2004, Fuhlendorf et al., 2009). Known as patch burn-grazing (McGranahan et al., 2012a), such heterogeneity-based management creates a landscape mosaic to support greater biodiversity than conventional, homogeneity-based management (Coppedge et al., 2008, Doxon et al., 2011, Engle et al., 2008, Fuhlendorf et al., 2006). As such, managers are often encouraged to promote landscape heterogeneity to conserve rangeland fauna (Toombs et al., 2010).

Relatively little research has tested the universality of the theory that heterogeneity-based management creates meaningful rangeland diversity, and even less has presented ex- perimental results in a manner accessible to environmental managers and policy-makers. We use a meta-analytical approach with data from five rangeland locations in the North American Great Plains to determine whether heterogeneitybased management (patch burn-grazing) increases spatial heterogeneity in four variables (vegetation structure, plant functional group composition, litter cover, and bare ground) when compared to conventional, homogeneity-based management (grazing without spatially discrete fire). Each variable is important to rangeland fauna, including birds, small mammals, and invertebrates (Table 1). We calculate an effect size for each variable at each location to compare the level of patch contrast - "the degree of difference between patches" (Kotliar and Wiens, 1990)_created by heterogeneity-based management versus homogeneity-based management. Although we do not expect all study locations to universally respond to heterogeneity-based management (McGranahan et al., 2012a), we predict that habitat variables should respond consistently within each location. We discuss these results with respect to conservation goal-setting and the evaluation of management outcomes.

\section{Methods}

\subsection{Data}

We used an existing dataset of five rangeland experiments in Oklahoma and Iowa, USA (McGranahan et al., 2012a). Experimental locations include: Cooper Wildlife Management Area, Woodward County, Oklahoma; Klemme Range Research Station, Washita County, Oklahoma; Oklahoma State University Range Research Station, Paine County, Oklahoma; Tallgrass Prairie Preserve, Osage County, Oklahoma; and the Grand River Grasslands, Ringgold County, Iowa. The experimental locations spanned a broad geographic range (ca. $650 \mathrm{~km}$ ) and represented different grassland types, tract

Table 1. Examples of habitat functions for rangeland wildlife associated with four vegetation variables analyzed in this study.

\begin{tabular}{|c|c|c|}
\hline Habitat variable & Observed wildlife response & References \\
\hline \multirow[t]{2}{*}{$\begin{array}{l}\text { Plant functional } \\
\text { group composition }\end{array}$} & $\begin{array}{l}\text { Conservation plantings comprised of grasses, legumes, and forbs increase } \\
\text { habitat value for ring-necked pheasant nesting and brood-rearing }\end{array}$ & Matthews et al. (2012) \\
\hline & Diversity of conservation plantings support diverse bird communities & Patterson and Best (1996) \\
\hline \multirow[t]{3}{*}{ Vegetation structure } & Sward height affects prey density, predation risk among insectivorous grassland birds & Atkinson et al. (2004) \\
\hline & Bird nest site selections based on vegetation structure, variable among species & Fondell and Ball (2004) \\
\hline & Grasshopper species richness increased with heterogeneous vegetation structure & Joern (2005) \\
\hline \multirow[t]{3}{*}{ Bare ground } & Ground-foraging birds depend on access to bare patches for food & $\begin{array}{l}\text { Tagmann-Ioset et al. (2012) } \\
\text { \& Atkinson et al. (2004) }\end{array}$ \\
\hline & Ca. $30 \%$ bare ground minimum habitat requirement for Mountain Plover & Knopf and Miller (1994) \\
\hline & Ant community composition affected by changes in bare ground & Graham et al. (2008) \\
\hline \multirow[t]{3}{*}{ Litter cover } & Litter cover $<25 \%$ doubled success rate of Greater Prairie-chicken nests & McKee et al. (1998) \\
\hline & Altered litter cover associated with altered ant community composition & Bestelmeyer and Wiens (1996) \\
\hline & Winter cover, greater soil moisture increase survival of grassland obligate butterflies & Vogel et al. (2010) \\
\hline
\end{tabular}


sizes, and management schemes (Table 2). Although established independently, the basic structure of each experiment was consistent: each experiment consisted of a replicated treatment in which fire was applied in spatially discrete patches, and a replicated control reflecting conventional management with homogeneous fire regimes. All pastures in all locations were stocked with cattle at moderate rates according to local USDA Natural Resource Conservation Service recommendations (Table 2). Cattle (Bos taurus) were allowed free access to water and grazing within each replicate pasture with no interior fences.

Data from all five locations consisted of vegetation structure (visual obstruction readings that combine measurements of vegetation height and density (Harrell and Fuhlendorf, 2002)) and canopy cover of plant functional groups, litter cover, and bare ground area following Daubenmire (1959) cover classes. At each location, data were collected with a nested hierarchical design in which pastures were divided into patches, and patches were divided into transects, along which sampling points were located (at the Tallgrass Prairie Preserve, sampling points were located within avian point count areas established within the same nested patch structure). For specific information about the experimental design and data collected at each location, see Supplementary information S1.

\subsection{Analysis}

To determine the effect of heterogeneity-based management, we calculated patch contrast for each variable within each treatment group at each location. We then calculated an effect size to compare the effect of heterogeneity-based management to homogeneity-based management at each location. Our statistical methodology is described below.

\subsubsection{Patch contrast}

To calculate patch contrast for vegetation structure, litter cover, and bare ground area, we used a linear mixed-effect (LME) regression model to determine the proportion of variation attributable to differences among patches (see also Winter et al., 2012). We created LME regression models with the lmer function in the nlme4 package for the R statistical environment (Bates and Maechler, 2010, R Development Core Team, 2011).

To calculate patch contrast in plant functional group composition, we used the unconstrained ordination NonMetric Multidimensional Scaling (NMDS) to determine the range of variation in plant functional group composition for pastures managed with heterogeneity versus pastures managed for homogeneity. Ordination is effective in calculating the range of variation in composition, a measure of contrast in plant functional group composition (McGranahan et al., 2012a). Range of variation was measured using site scores along NMDS axis 1 , the gradient of greatest variation in plant functional group composition. A separate ordination was performed for each location using the metaMDS function in the vegan package for the R statistical environment (Oksanen et al., 2011). To facilitate comparison of NMDS results across locations, variation in site scores was standardized to a common range with the scale function in R.

Table 2. Precipitation, vegetation, and stocking information for five experimental locations comparing heterogeneously applied fire management with homogeneous fire regimes. Refer to Methods and Supplementary data for experimental design, data collected, and years included. Locations listed geographically from west to east.

\begin{tabular}{|c|c|c|c|c|c|}
\hline Study location & Cooper ${ }^{a}$ & Klemme $^{\mathrm{b}}$ & Stillwater ${ }^{c}$ & TGPPd $^{d}$ & $\mathrm{GRG}^{\mathrm{e}}$ \\
\hline Long-term mean & 57 & 78 & 83 & 88 & 91 \\
\hline Vegetation type & $\begin{array}{l}\text { Artemisia shrubland- } \\
\text { mixed prairie }\end{array}$ & Midgrass prairie & Tallgrass prairie & Tallgrass prairie & Tallgrass prairie \\
\hline \multicolumn{6}{|l|}{ Stocking rate ${ }^{\mathrm{f}}$} \\
\hline Prior to study period & Moderate & Heavy & Moderate & Moderate-light & Severe \\
\hline Grazing season & 1 April-15 Sept. & 15 Mar.-15 Sept. & 1 Dec.-1 Sept. & 15 Apr.-20 Jul. & 1 May-1 Oct. \\
\hline Pasture area (ha) & $406-848$ & Ca. 50 & $45-65$ & 400-900 & $15-31$ \\
\hline \multicolumn{2}{|l|}{$\begin{array}{l}\text { Annual primary } \\
\text { productivity }^{(\mathrm{kg} / \mathrm{ha})}\end{array}$} & 2,000 & 5,600 & 6,000 & 7,000 \\
\hline $\begin{array}{l}\text { a. Hal and Fern Cooper Wi } \\
\text { b. Marvin Klemme Experin } \\
\text { c. Stillwater Research Rang } \\
\text { d. Tallgrass Prairie Preserv } \\
\text { e. Grand River Grasslands } \\
\text { f. Stocking rate categories } \\
\text { g. Estimated annual prima } \\
\text { (Gillen and Sims, 2004), } \\
\text { Unpublished data on en } \\
\text { annual primary producti } \\
\text { Table modified with permi }\end{array}$ & $\begin{array}{l}\text { fe Management Area (G } \\
\text { tal Research Range (Gi } \\
\text { Fuhlendorf and Engle, } \\
\text { Coppedge et al., 2008, H } \\
\text { M, } 2011 \text { and Pillsbury e } \\
\text { ressed in relation to loc } \\
\text { productivity of native ve } \\
\text { emme (Gillen et al., } 20 \\
\text { f-season biomass one y } \\
y \text { at the TGPP. }\end{array}$ & $\begin{array}{l}\text { en and Sims, } 2004 \text { a } \\
\text { n et al., } 2000 \text { and Li } \\
4, \text { Gillen et al., } 198 \\
\text { ailton, } 2007 \text { and Me } \\
\text { 1., 2011). } \\
\text { recommendations f } \\
\text { tation not recently } \\
\text {, Stillwater (Gillen } \\
\text { after fire from at le }\end{array}$ & $\begin{array}{l}\text { Winter et al., } 2012 \\
\text { et al., 2011). } \\
\text { imb et al., } 2011 \text { ar } \\
\text { let, 2011). } \\
\text { the USDA Natura } \\
\text { urbed by grazing } \\
\text { l., 1987), and the } \\
\text { one year within tl }\end{array}$ & $\begin{array}{l}\text { sonet, 2011). } \\
\text { ource Conservatio } \\
\text { tilization. Publish } \\
\text { d River Grassland. } \\
\text { dy period include }\end{array}$ & $\begin{array}{l}\text { ice. } \\
\text { a were used for Cooper } \\
\text { Granahan et al., 2013). } \\
\text { were used to estimate }\end{array}$ \\
\hline
\end{tabular}




\subsubsection{Effect size}

To express the effect of heterogeneity-based management versus homogeneity-based management on patch contrast among measured habitat variables with a single value, we calculated an effect size for each variable at each location. We calculated the meta-analytical statistic Cohen's $d$ (Cohen, 1977), which divides the difference between the mean of pastures managed for heterogeneity and the mean of pastures managed for homogeneity by the square root of the pooled standard deviation for each location. We also calculated $95 \%$ confidence intervals for each effect size statistic using an iterative procedure in R (McGranahan et al., 2012a).

\section{Results}

Response to heterogeneity-based management was not consistent across locations or within locations. At Cooper, Stillwater, and the Tallgrass Prairie Preserve, pastures managed for heterogeneity consistently demonstrated greater patch contrast in all four variables-plant functional group diversity, vegetation structure, bare ground, and litter cover-compared to pastures managed for homogeneity (Figure 1). However, effect sizes varied considerably across and within locations: for example, heterogeneity-based management had the greatest effect on bare ground at Cooper and the Tallgrass Prairie Preserve, but bare ground had the greatest response at Stillwater (Figure 1). At Klemme, the pattern was also consistent but effect size was not different than zero for any of the four variables (Figure 1).

In the Grand River Grasslands, the response to heterogeneity-based management was more complex. Effect sizes for heterogeneity-based management plant functional group composition and vegetation structure were not different than zero (Figure 1). But heterogeneity-based management did have an effect on bare ground and litter cover, and these responses

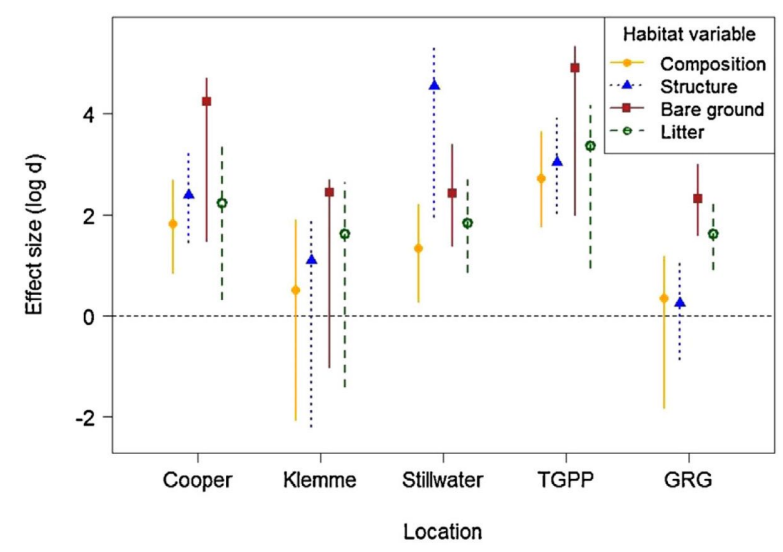

Figure 1. Effect size of four habitat variables at five rangeland locations in the North American Great Plains, comparing heterogeneity-based management (patch burn-grazing) to homogeneity-based management (grazing with homogeneous fire regimes). Effect sizes are plotted on a log scale. Study locations are ordered geographically from west to east and include four locations in Oklahoma-Cooper, Klemme, Stillwater, and the Tallgrass Prairie Preserve (TGPP)—and one in Iowa, the Grand River Grasslands (GRG). were similar to locations with consistent effects of heterogeneity-based management: In the Grand River Grasslands, bare ground had a similar response to Stillwater, and litter cover had a similar response to Cooper and Stillwater (Figure 1).

\section{Discussion}

Our data indicate that the effect of heterogeneity-based rangeland management is neither consistent across locations nor among variables within a given location. While these results inform our understanding of the regulators of the firegrazing interaction, they also offer important lessons in how habitat management objectives are set, implemented, and evaluated in the conservation of rangeland diversity.

\subsection{Relative impacts of severe grazing and invasive spe- cies on the fire-grazing interaction}

Under the fire-grazing interaction, herbivores preferentially follow the spatial pattern of fire on the landscape in response to high-quality forage in recently burned areas that is maintained by repeated grazing (Allred et al., 2011). However, severe grazing (the result of overstocking) and invasive species can weaken the influence of fire on the spatial pattern of grazing (McGranahan et al., 2012a) because they disrupt the continuity of the fuelbed and limit fire spread (McGranahan et al., 2013, Davies et al., 2010).

These results help parse the relative effect of overstocking and invasive species on the fire-grazing interaction. At Klemme, the impact of grazing just prior to the collection of our data was so severe as to create large gaps of bare ground that prevented fire spread (D. Engle and S. Fuhlendorf, pers. obs.) and limited the effect of heterogeneity-based management (Figure 1). Recent data, however, indicate that recovery from severe grazing at Klemme has increased the effect of heterogeneity-based management following the restoration of the fire-grazing interaction (Limb et al., 2011).

While grazing in the Grand River Grasslands prior to the collection of our data was also severe (Table 2), nonetheless heterogeneity-based management created patch contrast in two habitat variables-bare ground and litter cover-to a similar degree as in three of the Oklahoma rangelands. From a habitat standpoint, fire spread in the Grand River Grasslands was sufficient to remove litter and create bare ground in burned patches. We suggest that patch contrast in plant functional group composition and vegetation structure was limited less by previous overstocking and more by tall fescue (Schedonorus phoenix (Scop.) Holub) invasion, which homogenizes the plant community (McGranahan et al., 2012b) and reduces vegetation height in the absence of taller native grass species.

\subsection{Connecting habitat variables to responses of range- land fauna}

Managers of rangeland ecosystems are often encouraged to promote landscape heterogeneity under the assumption that habitat diversity begets species diversity (Derner et al., 2009, Toombs et al., 2010), and with due cause: heteroge- 
neously managed rangeland can have more diverse, dynamic communities of birds, invertebrates, and small mammals than comparable rangeland managed homogeneously (Table 3). Not surprisingly, enhanced biodiversity under heterogeneitybased management is observed at the same three locationsCooper, Stillwater, and the Tallgrass Prairie Preserve-where heterogeneity-based management consistently created patch contrast in the four variables tested here (Figure 1).

Other studies that compare the effect of heterogeneityversus homogeneity-based management on avian and invertebrate communities show mixed results (Table 3). For example, in the Grand River Grasslands, grassland bird communities were similar in pastures managed for heterogeneity as compared to pastures managed for homogeneity, although bird communities in pastures under heterogeneity-based management appeared to differentiate over time from pastures managed with homogeneous fire regimes (Pillsbury et al., 2011). Likewise, invertebrate community responses to heterogeneitybased management were weak, with differences in community composition driven primarily by pasture-level land use history (Debinski et al., 2011, Moranz et al., 2012).

Despite the lack of a consistent, community-level response as demonstrated at Cooper, Stillwater, and the Tallgrass Prairie Preserve, certain species in the Grand River Grasslands did show a response to heterogeneity-based management.
As one example, Grasshopper Sparrow (Ammodramus savannarum) nest survival was greater under heterogeneity-based management than homogeneity-based management (Hovick et al., 2012). This suggests that some species might respond to those habitat variables that did show a response to heterogeneity-based management in the Grand River Grasslands, namely litter cover and bare ground (Figure 1). In fact, Hovick et al. (2012) specifically recommend decreasing vegetation cover to increase Grasshopper Sparrow survival and cite heterogeneity-based management as a tool. These recommended outcomes are measured here as patch contrast in bare ground, litter cover and vegetation structure, two of which were successful in the Grand River Grasslands.

\subsection{Evaluation of rangeland management must match policy objectives}

Painted broadly, effective conservation science and policy begins with stating clear goals and defining measurable objectives (Eyre et al., 2011, Tear et al., 2005). But specific goals and evaluation measures are often species- or ecosystem-dependent, and simply applying a given management practice is not a conservation endpoint. Our comparison of four measures of heterogeneity-based management across five rangeland locations indicates that a universal response from a practice should not be assumed. Two lessons follow:

Table 3. Summarized literature review of wildlife responses to heterogeneity-based management (HBM) from four rangeland locations in Oklahoma and Iowa, USA. A fifth location used in this study, the Klemme Range Research Station in southwestern Oklahoma, is not included in this table because no relevant wildlife research was found in our literature review.

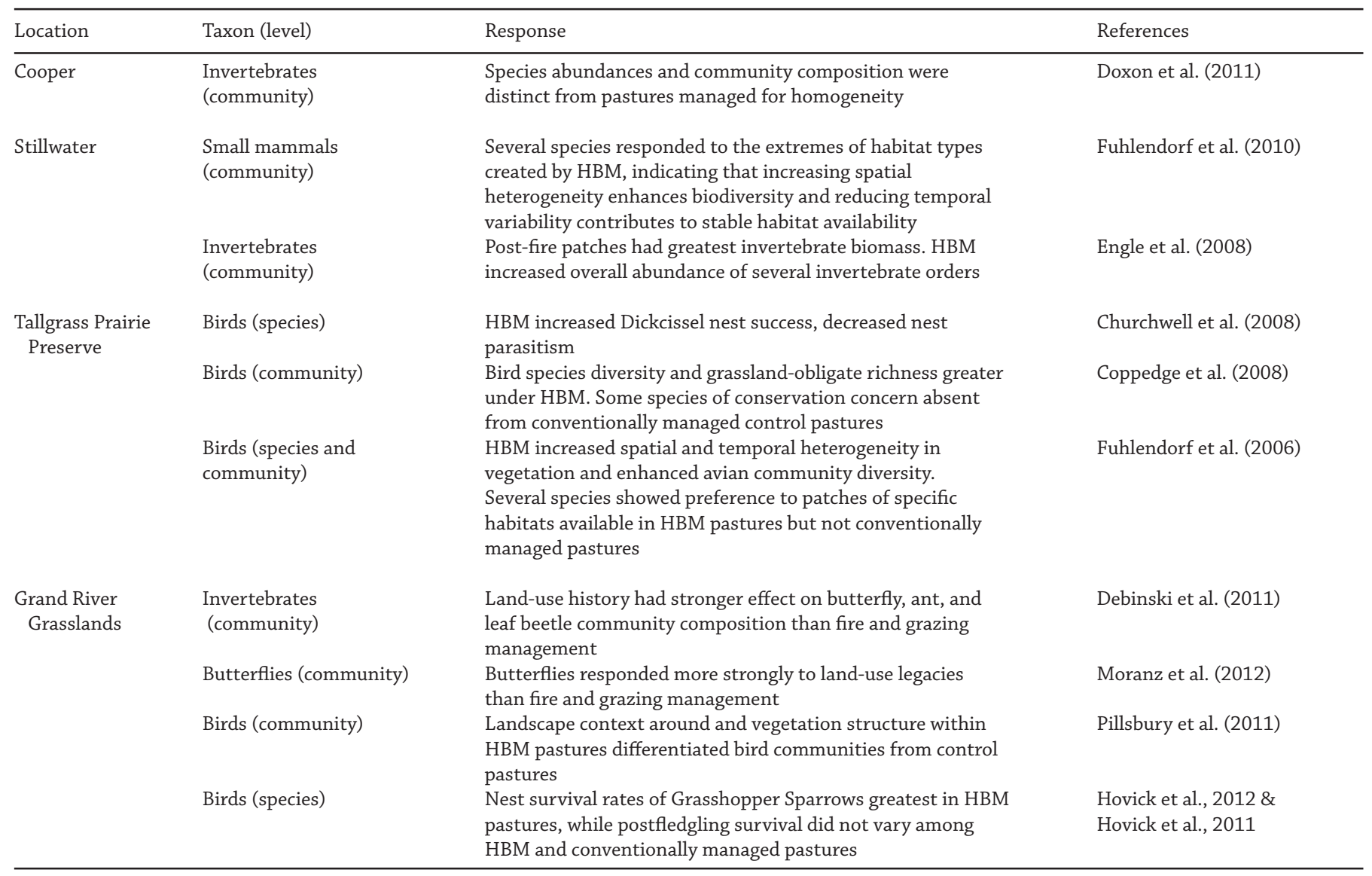


(1) managers attempting to accomplish a breadth of conservation objectives with a single practice must evaluate specific outcomes, and (2) a lack of demonstrated success in one outcome does not necessarily mean that management has failed to advance the conservation needs of individual species.

These lessons prompt a reflection on a frequent approach in conservation science: the umbrella or focal species concept, in which managers focus on the needs of one or several specific species whose needs envelope the requirements of other species in the community (Lambeck, 1997, Roberge and Angelstam, 2004). In North America, grassland bird populations have declined precipitously following agricultural expansion (Samson and Knopf, 1994), and prairie grouse species such as the Greater Prairie Chicken (Tympanuchus cupido pinnatus) are considered umbrella species for the conservation of grassland ecosystems (e.g., Poiani et al., 2001) because their life histories require a breadth of habitat-i.e., a high degree of contrast in the landscape in each of the variables considered here. Alternatives to umbrella species include the keystone structure concept, in which managers seek to identify and promote spatial structure that provides resources necessary for other species (Tews et al., 2004). Such a bottom-up approach might be more inclusive of a wide variety of rangeland fauna and help managers identify common habitat needs, rather than assume that management for a single species supports the community.

To be sure, we do not intend to undermine the umbrella species concept; rather, we use our results to remind conservation scientists and policy-makers that the needs of one species of conservation concern might be met even if the needs of other species are not. While heterogeneity-based management has been shown to meet the needs of rangeland umbrella species like prairie grouse (Derner et al., 2009, Patten et al., 2007), individual species can benefit from specific habitat outcomes even if the entire community does not show a consistent response to management (Hovick et al., 2012, Moranz et al., 2012, Powell, 2008). Although desirable, it is not necessary for environmental management to meet the conservation needs of every species, nor are conservation projects necessarily unsuccessful if the needs of the entire community are not met. What is important is that managers set realistic conservation goals and match their evaluation to their objectives, i.e., measure the proper response variable(s) for the desired conservation outcome.

Acknowledgments - We acknowledge the following support: the Iowa State Wildlife Grants program through the United States Fish and Wildlife Service Wildlife and Sport Fish Restoration Program (\#T-1-R-15); the Joint Fire Science Program (\#201814G905); the USDA Cooperative State Research, Education and Extension Service National Research Initiative (\#2006-35320-17476); the Oklahoma Agricultural Experiment Station; and the Mellon Foundation through the Associated Colleges of the South environmental postdoctoral scholar program. We appreciate the contributions of R. Harr, R. Limb, B. Allred, J. Kerby, M. Kirkwood, P. Dixon, C. Goad and K. Pazdernick.
Appendix A. Supplementary data appears following the References.

\section{References}

Allred, B. W., Fuhlendorf, S. D., Engle, D. M., Elmore, R. D., 2011. Ungulate preference for burned patches reveals strength of firegrazing interaction. Ecology and Evolution 1, 132-144.

Atkinson, P. W., Buckingham, D., Morris, A. J., 2004. What factors determine where invertebrate-feeding birds forage in dry agricultural grasslands? Ibis 146, 99-107.

Bates, D., Maechler, M., 2010. lme4: Linear mixed-effect models using $\mathrm{S} 4$ classes.

Benton, T. G., Vickery, J. A., Wilson, J. D., 2003. Farmland biodiversity: Is habitat heterogeneity the key? Trends in Ecology \& Evolution 18, 182-188.

Bestelmeyer, B. T., Wiens, J. A., 1996. The effects of land use on the structure of ground-foraging ant communities in the Argentine Chaco. Ecological Applications 6, 1225-1240.

Churchwell, R. T., Davis, C. A., Fuhlendorf, S. D., Engle, D. M., 2008. Effects of patch-burn management on dickcissel nest success in a tallgrass prairie. Journal of Wildlife Management 72, 1596-1604.

Cohen, J., 1977. Statistical Power Analysis for the Behavioral Sciences. Academic Press, New York, NY.

Coppedge, B., Fuhlendorf, S. D., Harrell, W. C., Engle, D. M., 2008. Avian community response to vegetation and structural features in grasslands managed with fire and grazing. Biological Conservation 141, 1196-1203.

Daubenmire, R., 1959. A canopy-coverage method of vegetational analysis. Northwest Science 33, 43-64.

Davies, K. W., Bates, J. D., Svejcar, T. J., Boyd, C. S., 2010. Effects of long-term livestock grazing on fuel characteristics in rangelands: An example from the sagebrush steppe. Rangeland Ecology \& Management 63, 662-669.

Debinski, D. M., Moranz, R. A., Delaney, J. T., Miller, J. R., Engle, D. M., Winkler, L. B., McGranahan, D. A., Barney, R. J., Trager, J. C., Stephenson, A. L., Gillespie, M. K., 2011. A cross-taxonomic comparison of insect responses to grassland management and land-use legacies. Ecosphere 2, art131.

Derner, J. D., Lauenroth, W. K., Stapp, P., Augustine, D. J., 2009. Livestock as ecosystem engineers for grassland bird habitat in the western Great Plains of North America. Rangeland Ecology \& Management 62, 111-118.

Doxon, E. D., Davis, C. A., Fuhlendorf, S. D., Winter, S. L., 2011. Aboveground macroinvertebrate diversity and abundance in sand sagebrush prairie managed with the use of pyric herbivory. Rangeland Ecology \& Management 64, 394-403.

Drechsler, M., Johst, K., Ohl, C., Wätzold, F., 2007. Designing costeffective payments for conservation measures to generate spatiotemporal habitat heterogeneity. Conservation Biology 21, 1475-1486.

Engle, D. M., Fuhlendorf, S. D., Roper, A., Leslie Jr., D. M., 2008. Invertebrate community response to a shifting mosaic of habitat. Rangeland Ecology \& Management 61, 55-62.

Eyre, T. J., Fisher, A., Hunt, L. P., Kutt, A. S., 2011. Measure it to 
better manage it: A biodiversity monitoring framework for the Australian rangelands. Rangeland Journal 33, 239-253.

Fischer, J., Brosi, B., Daily, G. C., Ehrlich, P. R., Goldman, R., Goldstein, J., Lindenmayer, D. B., Manning, A. D., Mooney, H. A., Pejchar, L., Ranganathan, J., Tallis, H., 2008. Should agricultural policies encourage land sparing or wildlife-friendly farming? Frontiers in Ecology and the Environment 6, 380-385.

Fischer, J., Lindenmayer, D. B., Manning, A. D., 2006. Biodiversity, ecosystem function, and resilience: Ten guiding principles for commodity production landscapes. Frontiers in Ecology and the Environment 4, 80-86.

Fondell, T., Ball, I. J., 2004. Density and success of bird nests relative to grazing on western Montana grasslands. Biological Conservation 117, 203-213.

Franklin, J. F., Lindenmayer, D. B., 2009. Importance of matrix habitats in maintaining biological diversity. Proceedings of the $\mathrm{Na}-$ tional Academy of Sciences of the United States of America 106, 349.

Fraterrigo, J. M., Rusak, J. A., 2008. Disturbance-driven changes in the variability of ecological patterns and processes. Ecology Letters 11, 756-770.

Fuhlendorf, S. D., Engle, D. M., 2004. Application of the fire- grazing interaction to restore a shifting mosaic on tallgrass prairie. Journal of Applied Ecology 41, 604-614.

Fuhlendorf, S. D., Engle, D. M., Kerby, J., Hamilton, R., 2009. Pyric herbivory: Rewilding landscapes through the recoupling of fire and grazing. Conservation Biology 23, 588-598.

Fuhlendorf, S. D., Harrell, W. C., Engle, D. M., Hamilton, R. G., Davis, C. A., Leslie Jr., D. M., 2006. Should heterogeneity be the basis for conservation? Grassland bird response to fire and grazing. Ecological Applications 16, 1706-1716.

Fuhlendorf, S. D., Townsend, D. E., Elmore, R. D., Engle, D. M., 2010. Pyric-herbivory to promote rangeland heterogeneity: Evidence from small mammal communities. Rangeland Ecology \& Management 63, 670-678.

Gillen, R. L., Eckroat, J. A., McCollum, F. T., 2000. Vegetation response to stocking rate in southern mixed-grass prairie. Journal of Range Management 53, 471-478.

Gillen, R. L., Rollins, D., Stritzke, J. F., 1987. Atrazine, spring burning, and nitrogen for improvement of tallgrass prairie. Journal of Range Management 40, 444-447.

Gillen, R. L., Sims, P. L., 2004. Stocking rate, precipitation, and herbage production on sand sagebrush-grassland. Journal of Range Management 57, 148-152.

Graham, J. H., Krzysik, A. J., Kovacic, D. A., Duda, J. J., Freeman, D. C., Emlen, J. M., Zak, J. C., Long, W. R., Wallace, M. P., Chamberlin-Graham, C., Nutter, J. P., Balbach, H. E., 2008. Ant community composition across a gradient of disturbed military landscapes at Fort Benning, Georgia. Southeastern Naturalist 7, 429-448.

Hamilton, R. G., 2007. Restoring heterogeneity on the Tallgrass Prairie Preserve: Applying the fire-grazing interaction model. In: Proceedings of the 23rd Tall Timbers Fire Ecology Conference: Fire in Grassland and Shrubland Ecosystems. Allen Press, Tall Timbers Research Station, Tallahassee, Florida, USA, pp. 163-169.
Harrell, W. C., Fuhlendorf, S. D., 2002. Evaluation of habitat structural measures in a shrubland community. Journal of Range Management 55, 488-493.

Hovick, T. J., Miller, J. R., Dinsmore, S. J., Engle, D. M., Debinski, D. M., Fuhlendorf, S. D., 2012. Effects of fire and grazing on grasshopper sparrow nest survival. Journal of Wildlife Management 76, 19-27.

Hovick, T. J., miller, J. R., Koford, R. R., Engle, D. M., Debinski, D. M., 2011. Postfledging survival of grasshopper sparrows in grasslands managed with fire and grazing. Condor 113, $429-437$.

IEM, 2011. Iowa Environmental Mesonet, Iowa State University Department of Agronomy, Lamoni, IA Online: $\quad$ http://mesonet.agron.iastate.edu/climodat/index. phtml?station=IA4585\&report=17 (accessed 5/31/11).

Joern, A., 2005. Disturbance by fire frequency and bison grazing modulate grasshopper assemblages in tallgrass prairie. Ecology 86, 861-873.

Knopf, F. L., Miller, B. J., 1994. Charadrius montanus: Montane, grassland, or bare-ground plover? Auk 111, 504-506.

Kotliar, N. B., Wiens, J. A., 1990. Multiple scales of patchiness and patch structure: A hierarchical framework for the study of heterogeneity. Oikos 59, 253-260.

Lambeck, R. J., 1997. Focal species: A multi-species umbrella for nature conservation. Conservation Biology 11, 849-856.

Limb, R. F., Fuhlendorf, S. D., Engle, D. M., Weir, J. R., Elmore, R. D., Bidwell, T. G., 2011. Pyric-herbivory and cattle performance in grassland ecosystems. Rangeland Ecology \& Management 64, 659-663.

Matthews, T. W., Taylor, J. S., Powell, L. A., 2012. Ring-necked pheasant hens select managed Conservation Reserve Program grasslands for nesting and brood-rearing. Journal of Wildlife Management 76, 1653-1660.

McGranahan, D. A., Engle, D. M., Fuhlendorf, S. D., Winter, S. J., Miller, J. R., Debinski, D. M., 2012a. Spatial heterogeneity across five rangelands managed with pyric-herbivory. Journal of Applied Ecology 49, 903-910.

McGranahan, D. A., Engle, D. M., Miller, J. R., Debinski, D. M., 2013. An invasive grass increases live fuel proportion and reduces fire spread in a simulated grassland. Ecosystems 16, 158-169.

McGranahan, D. A., Engle, D. M., Wilsey, B. J., Fuhlendorf, S. D., Miller, J. R., Debinski, D. M., 2012b. Grazing and an invasive grass confound spatial pattern of exotic and native grassland plant species richness. Basic and Applied Ecology 13, 654- 662.

McKee, G., Ryan, M. R., Mechlin, L. M., 1998. Predicting Greater Prairie-Chicken nest success from vegetation and landscape characteristics. Journal of Wildlife Management 62, 314-321.

Moranz, R. A., Debinski, D. M., McGranahan, D. A., Engle, D. M., Miller, J. R., 2012. Untangling the effects of fire, grazing, and land-use legacies on grassland butterfly communities. Biodiversity and Conservation 21, 2719-2746.

Ohl, C., Drechsler, M., Johst, K., Wa“ tzold, F., 2008. Compensation payments for habitat heterogeneity: Existence, efficiency, and fairness considerations. Ecological Economics 67, 162- 174.

OK Mesonet, 2011. Oklahoma Mesonet. Online: http://www.mesonet.org (accessed 06/23/11). 
Oksanen, J., Blanchet, F. G., Kindt, R., Legendre, P., O’Hara, R. G., Simpson, G. L., Solymos, P., Stevens, M. H. H., Wagner, H., 2011. vegan: community ecology package. Online: http://cran.r-project.org/package=vegan (accessed 1/25/11).

Ostfeld, R. S., 1997. Defining the scientific issues. In: Pickett, S. T., Shachak, M., Likens, G. E., Ostfeld, R. S., eds., The Ecological Basis of Conservation: Heterogeneity, Ecosystems, and Biodiversity. Chapman and Hall, NY, New York, pp. 3-10.

Patten, M. A., Shochat, E., Wolfe, D. H., Sherrod, S. K., 2007. Lekking and nesting response of the Greater Prairie-Chicken to burning of tallgrass prairie. In: Proceedings of the Tall Timbers Fire Ecology Conference. pp. 149-155.

Patterson, M. P., Best, L. B., 1996. Bird abundance and nesting success in Iowa CRP fields: The importance of vegetation structure and composition. American Midland Naturalist 135, 153-167.

Pickett, S. T. A., White, P. S. (Eds. ), 1985. The ecology of natural disturbance and patch dynamics. Academic Press, New York, NY.

Pillsbury, F. C., Miller, J. R., Debinski, D. M., Engle, D. M., 2011. Another tool in the toolbox? Using fire and grazing to promote bird diversity in highly fragmented landscapes. Ecosphere 2, article 28.

Poiani, K. A., Merrill, M. D., Chapman, K. A., 2001. Identifying conservation-priority areas in a fragmented Minnesota landscape based on the umbrella species concept and selection of large patches of natural vegetation. Conservation Biology 15, 513-522.

Powell, A. F. L. A., 2008. Responses of breeding birds in tallgrass prairie to fire and cattle grazing. Journal of Field Ornithology 79, 41-52.

R Development Core Team, 2011. R: A Language and Environment for Statistical Computing. R Foundation for Statistical Computing, Vienna, Austria.

Ricketts, T. H., Daily, G. C., Ehrlich, P. R., Fay, J. P., 2001. Countryside biogeography of moths in a fragmented landscape: Biodiversity in native and agricultural habitat. Conservation Biology 15, 378-388.

Roberge, J. M., Angelstam, P., 2004. Usefulness of the umbrella species concept as a conservation tool. Conservation Biology 18, 76-85.
Samson, F., Knopf, F., 1994. Prairie conservation in North America. BioScience 44, 418-421.

Tagmann-Ioset, A., Schaub, M., Reichlin, T. S., Weisshaupt, N., Arlettaz, R., 2012. Bare ground as a crucial habitat feature for a rare terrestrially foraging farmland bird of Central Europe. Acta Oecologica 39, 25-32.

Tear, T. H., Kareiva, P., Angermeier, P. L., Comer, P., Czech, B., Kautz, R., Landon, L., Mehlman, D., Murphy, K., Ruckelshaus, M., et al., 2005. How much is enough? The recurrent problem of setting measurable objectives in conservation. BioScience 55, 835-849.

Tews, J., Brose, U., Grimm, V., Tielbörger, K., Wichmann, M. C., Schwager, M., Jeltsch, F., 2004. Animal species diversity driven by habitat heterogeneity/diversity: The importance of keystone structures. Journal of Biogeography 31, 79-92.

Toombs, T. P., Derner, J. D., Augustine, D. J., Krueger, B., Gallagher, S., 2010. Managing for biodiversity and livestock. Rangelands 32, 10-15.

Toombs, T. P., Roberts, M. G., 2009. Are natural resources conservation service range management investments working at crosspurposes with wildlife habitat goals on western United States rangelands? Rangeland Ecology \& Management 62, 351-355.

Vogel, J. A., Koford, R. R., Debinski, D. M., 2010. Direct and indirect responses of tallgrass prairie butterflies to prescribed burning. Journal of Insect Conservation 14, 663-677.

Wallington, T. J., Hobbs, R. J., Moore, S. A., 2005. Implications of current ecological thinking for biodiversity conservation: a review of the salient issues. Ecology and Society 10, 16.

Wiens, J. A., 1997. The emerging role of patchiness in conservation biology. In: Pickett, S. T., Ostfeld, R. S., Shachak, M., Likens, G. E., eds., The Ecological Basis of Conservation: Heterogeneity, Ecosystems, and Biodiversity. Chapman and Hall, NY, New York, pp. 93-107.

Winter, S. L., Fuhlendorf, S. D., Goad, C. L., Davis, C. A., Hickman, K. R., Leslie Jr., D. M., 2012. Restoration of the fire-grazing interaction in Artemisia filifolia shrubland. Journal of Applied Ecology 49, 242-250. 


\section{Supplementary Information S1. Description of data included in range- land heterogeneity analysis}

\section{Cooper Wildlife Management Area (Cooper)}

Woodward County, Oklahoma $\left(99^{\circ} 30^{\prime} \mathrm{W} 36^{\circ} 32^{\prime} \mathrm{N}\right)$

Treatment and replication: Heterogeneously-managed pastures $(\mathrm{N}=3)$ divided into three patches each (one patch burned each spring). Homogeneously-managed pastures $(\mathrm{N}=2)$ remained unburned during the duration of the study.

Sampling design: 10, 0.10- $\mathrm{m}^{2}$ quadrats located along each of four, 100-m transects per patch.

Data collected: Visual obstruction reading to nearest $\mathrm{cm}$ for vegetation structure; plant functional groups included live and dead vegetation, live and dead grass, live and dead forbs, and live and dead shrubs. Litter and bare ground percentage cover. Data collection spanned 21 May - 16 June, 2006-2008 inclusive. See Winter (2012).

\section{Marvin Klemme Range Research Station (Klemme)}

Washita County, Oklahoma $\left(99^{\circ} 04^{\prime} \mathrm{W} 35^{\circ} 25^{\prime} \mathrm{N}\right)$

Treatment and replication: Heterogeneously-managed pastures $(\mathrm{N}=2)$ divided into eight patches each (two patches burned annually). Homogeneously-managed pastures $(\mathrm{N}=2)$ remained unburned during the duration of the study.

Sampling design: 30, 0.10- $\mathrm{m}^{2}$ quadrats per patch.

Data collected: Angle of obstruction for vegetation structure; plant functional groups included shortgrasses, tallgrasses, annual grasses, perennial grasses, legumes, sedges, shrubs, forbs, and snakeweed (Gutierrezia sarothrae (Pursh) Britton \& Rusby). Litter and bare ground percentage cover. Data from 19992001 inclusive in addition to 2003 and 2006 for vegetation structure data; plant functional group data limited to 2003 and 2006. See Limb et al. $(2011,2009)$.

\section{Oklahoma State University Range Research Station (Stillwater)}

Paine County, Oklahoma ( $\left.99^{\circ} 04^{\prime} \mathrm{W} 36^{\circ} 22^{\prime} \mathrm{N}\right)$

Treatment and replication: Heterogeneously-managed pastures $(\mathrm{N}=3)$ divided into six patches each (two patches burned annually). Homogeneously-managed pastures $(\mathrm{N}=3)$ remained unburned for the period included here.

Sampling design: 30, 0.10- $\mathrm{m}^{2}$ quadrats randomly located within each patch in each pasture.

Data collected: Angle of obstruction for vegetation structure; plant functional groups included tallgrasses, little bluestem (Schizachyrium scoparium (Michx.) Nash), perennial grasses, annual grasses, forbs, sericea lespedeza (Lespedeza cuneata (Dum. Cours.) G. Don), and legumes. Litter and bare ground percentage cover. Data were collected in late August-early September, 1999-2001 inclusive. See Fuhlendorf \& Engle (2004) and Limb et al. (2011).

\section{Tallgrass Prairie Preserve (TGPP)}

Osage County, Oklahoma $\left(96^{\circ} 25^{\prime} \mathrm{W} 36^{\circ} 50^{\prime} \mathrm{N}\right)$

Treatment and replication: Heterogeneously-managed pastures $(\mathrm{N}=2)$ divided into six patches each (two patches burned annually). Homogeneously-managed pastures $(\mathrm{N}=2)$ were burned completely each spring.

Sampling design: 20, $0.10-\mathrm{m}^{2}$ quadrats located within each of four, $100-\mathrm{m}$ radius avian point count locations per patch. 
Data collected: Angle of obstruction for vegetation structure; plant functional groups included tallgrasses, shortgrasses, graminoids, forbs, shrubs. Litter and bare ground percentage cover. Data were collected in mid-May, 2001-2003 inclusive. See Coppedge et al. (2008).

\section{Grand River Grasslands (GRG)}

Ringgold County, Iowa $\left(94^{\circ} 08^{\prime} \mathrm{W} 40^{\circ} 35^{\prime} \mathrm{N}\right)$

Treatment and replication: Heterogeneously- managed pastures $(\mathrm{N}=4)$ were divided into three patches each (one patch burned each spring). Homogeneously-managed pastures $(\mathrm{N}=4)$ were burned in their entirety every third year (these data include one such burn year, 2009).

Sampling design: $30,0.50-\mathrm{m}^{2}$ quadrats per patch were distributed evenly along two parallel transects, 50-m apart, which straddled transects established for avian counts. Avian transects were laid out to maximize the sampled area within each patch, and numbered 2-3 transects/patch depending on patch geometry.

Data collected: Visual obstruction readings for vegetation structure; plant functional groups included warm-season grasses, cool-season grasses, tall fescue (Schedonorus phoenix (Scop.) Holub), forbs, legumes, and woody species. Litter and bare ground percentage cover. Data were collected early-mid July, 2007-2010 inclusive. See Pillsbury et al. (2011).

\section{References}

Coppedge, B., Fuhlendorf, S.D., Harrell, W.C., Engle, D.M., 2008. Avian community response to vegetation and structural features in grasslands managed with fire and grazing. Biol. Cons. 141, 1196-1203.

Fuhlendorf, S.D., Engle, D.M., 2004. Application of the fire-grazing interaction to restore a shifting mosaic on tallgrass prairie. J Appl Ecol 41, 604-614.

Limb, R.F., Fuhlendorf, S.D., Engle, D.M., Weir, J.R., Elmore, R.D., Bidwell, T.G., 2011. Pyricherbivory and cattle performance in grassland ecosystems. Rangeland Ecology and Management 64, 659-663.

Limb, R.F., Fuhlendorf, S.D., Townsend, D.E., 2009. Heterogeneity of thermal extremes: Driven by disturbance or inherent in the landscape. Environmental Management 43, 100-106.

Pillsbury, F.C., Miller, J.R., Debinski, D.M., Engle, D.M., 2011. Another tool in the toolbox? Using fire and grazing to promote bird diversity in highly fragmented landscapes. Ecosphere 2, art28.

Winter, S.L., Fuhlendorf, S.D., Goad, C.L., Davis, C.A., Hickman, K.R., Leslie Jr, D.M., 2012. Restoration of the fire-grazing interaction in Artemisia filifolia shrubland. J Appl Ecol 49, 242-250. 